matter, and when one considers the size and lack of complexity of the book it appears that we must blame the publishors for being somewhat dilatory. This is a book on a topic of rapidly increasing importance which needed to be written but which seems to have fallen short in its execution. Cancer research workers who are willing and able to find their way around the tortuosities of the production will undoubtedly find something of value. Tho authors of books to come will be grateful to the present authors for having provided them with such an excellent list of references to the work before 1965. J. O. LAaws

\section{BIOLOGY IN BRIEF}

\section{Embryologie}

By Charles Houillon. (Collection Méthodes.) Pp. 184. (Paris: Hermann, 1967.) 27 francs.

\section{Sexualité}

By Charles Houillon. (Collection Méthodes.) Pp. 197. (Paris: Hormann, 1967.) 27 francs.

\section{La Cellule}

By M. Durand et P. Favard. (Collection Méthodes.) Pp. 223. (Paris: Hormann, 1967.) 30 francs.

THESE three French books are part of a series of singletopic texts appropriate, in English terms, for the sixth former and early undergraduate. They have a good format, the writing is well organized and the illustrations are clear and relevant. There is, however, a tendency to tell the reader a subject is interesting rather than to cultivate his interest through stimulating prose or by bringing out the intollectual appoal of the subject.

Embryologie commences with a very brief historical account of embryological studies and a short, generalized review of stages in dovelopmental processes. The dovelopment of amphibia, birds and mammals is considered in detail; indeed the book deals almost exelusively with vertobrates. Thore is a final section on experimental embryology which suffers from not being integrated well with the other topies.

This book could oasily have been written a decade or more ago. There is no reference to dovelopmental genetics or any real consideration of the role of the nuclous. Possibly this rosultod from a policy of keeping the subject matter of each of the books in the series distinct. For the student it is a serious omission becauso it placos the subject in an unreal and inconaplete context.

Sexualité deals only with animals, mainly vertebrates. The first major section is a short but useful discussion of the concept of the continuity of the germ plasm in relation to modern findings. Spermatogenesis, oogenesis and fertilization are then each considered in some detail. There is a final section on the development of the urino-genital systems of vertebrates including a review of the determinants of sexual differences.

To some extent S'exualité covers some of the omissions of Embryologie. In the day of the large textbook they would have been sections. However, the reason for producing smaller books is not just to make them easior to carry. 'The limitation of size should stimulate an author to rethink his subject and to glean essential and relovant concepts. He should depiet a way of looking at the subject which will encourage the student to explore it not only within the frame of reference presented by tho book but also in comparison with other accounts. In this respect Sexualite is better than Embryologie, but it would be unreasonable to recommend either because thero nro already several books in English that compare more than favourably with them.

La Cellule is concerned mainly with coll chemistry, but therc are also sections on cell morphology and technicyus. 'Throughout the bonk thero is a refreshing respect for the critical assessment of evidenee and technique. As a survey of the field it is comprehensive and to the point. It exceeds the requirements of the sixth former, but for an undergraduate it would be a profitable way of using his "French for Seiontists".

P. J. KELIY

\section{MICROSCOPY FOR BEGINNERS}

\section{Introduction to Microscopy}

By G. W. White. Pp. vii +255. (London: Butterworth and Co. (Publishers), Ltd., 1966.) $30 s$.

Scinntists and technologists who make use of the microscope come from many different disciplines, ranging from clinicians and morphologists on the one hand to metallurgists, engineers and physicists on the other. For most of these workers, microscopy is not an end in itself and few of them have received formal training in the technique. As a result many have to acquire knowledge and experience during the course of their work. $\mathrm{Mr}_{\mathrm{r}}$ White's aim in writing this book is to smooth the path for those students, technicians and graduates who are commencing the use of the microscope.

The book includes a chapter on the history and one on the construction and care of the microscope. Four chapters are devoted to optical theory and construction, and a further chapter to setting the instrument up. There follow three chapters on specimen preparation, and three further ones doaling with measurements, mothods of illumination and photomicrography. The final chapter is an attempt to cover the material omitted in the previous chapters.

The material on theory, construction and setting up of the instrument is, on the whale, well covered at a suitably elementary level. The sections on preparation of specimens contain uscful matcrial although they sometimes appear to be written more from the point of view of the amatcur enthusiast than that of the budding professional. Some of the mothods given are not standard practice in histological laboratories.

While admitting the vastness of the field of microseopy and the consequent enforced selection of matorial for at book of this kind, the choicc of material is not always satisfactory. For example, while dispersion staining gets three pages, electron microseopy is dismissed in two. Phase contrast and interference techniques likewise get scant treatment.

The book can, howover, be recommended as an informative elementary account of light microscopy. The book is pleasant to read and the author's onthusiasm is evident.

M. A. Wilimams

\section{FIRST CATCH YOUR BEE}

\section{Trap-Nesting Wasps and Bees}

Life Histories, Nests, and Associates. By Karl V. Krombein. Pp. xi +570 . (Washington, D.C.: The Smithsonian Press, 1967.) $\$ 12.50$.

For many years people interested in the natural history of solitary bees and wasps that normally nest in, for oxample, turnels in wooden posts and plant stems have put drinking-straws, dead bramble stems, and other artificial nest-sites in places frequented by these insects in the hope of attracting them (here called "trap-nesting"). During the past few years, such techniques have been developed considerably, particularly in North Amcrica, in attempts to increase the numbers of those solitary bees known to be useful specialist pollinators of certain crops, such as lucerno.

Dr Krombein, who describes the improvements he has made in this technique, is a systematist who believes that 